LiNGUACULTURE 1, 2018

\title{
EVALUATIVE ADJECTIVES IN THE PORTRAYAL OF VICTORIAN WOMEN
}

\author{
LYUDMYLA GRYZHAK \\ Yuriy Fedkovych Chernivtsi National University
}

\begin{abstract}
The focus of this paper is the analysis of evaluative adjectives used in the description of physical appearance, clothing, personal qualities, intelligence and manners of female characters in the English prose fiction of the 19th century. Four novels written by the Victorian writers, approximately in the same time period, served as the source material for the research, namely E. Bronte's "Wuthering Heights” (1847), W. M. Thackeray’s “Vanity Fair” (1847), E. Gaskell’s “Cranford” (1851), and C. Dicken’s “Bleak House” (1852).

Evaluative adjectives are regarded in this paper as the ones that carry in their use an implication of a positive or negative attitude or evaluation on the part of the writer (beautiful, awful, etc.). They give an emotive or subjective characterization of the qualities of the referent, revealing the writer's or speaker's peculiar attitude towards the object described. The present paper has two aims. The first is to study what evaluative adjectives were mostly employed by the authors in the portrayals of women in each of the mentioned novels and whether the authors prefer positive or negative characterisation of female characters. The second one is to examine if there are any gender specific peculiarities in the use of evaluative adjectives in the portrayal of women in the novels.
\end{abstract}

Keywords: evaluative adjective, positive evaluation, negative evaluation, women characters, Victorian era

\section{INTRODUCTION}

Recently, the concept of evaluation has interested many linguists. It has been studied from different perspectives and has received a variety of names, e.g. 'affect' (cf. Ochs, Schieffelin 1989), 'stance' (cf. Biber et al. 1999), 'evaluation' (cf. Thompson and Hunston 2000), 'appraisal' (cf. Martin and White 2005), and some others. In the present paper, evaluation is understood

*l.gryzhak@chnu.edu.ua 
as "the broad cover term for the expression of the speaker or writer's attitude or stance towards, viewpoint on, feelings about the entities or propositions that he or she is talking about" (Thompson and Hunston 5). The study is a combination of semantic and pragmatic views on the use of evaluative adjectives in prose fiction.

Evaluative adjectives are analysed with a purpose to show how the novelists of the Victorian era of the development of the English literature described women characters whether the authors gave them a positive or negative characterisation and whether there are any gender differences in the use of evaluative adjectives in the portrayal of women in the novels.

\section{LINGUISTIC ASPECTS OF EVALUATION}

Evaluation is an essential and crucial feature of human categorization of the objective reality. It is a subjective critical attitude or opinion of various objects, phenomena, people, etc. that a person forms in the course of her/ his activities and it is closely related to cognition and emotion. As a social being, a person may correlate her/ his system of values with the social ones. In this respect Escandell-Vidal, Aguiar and Ocón noted that:

"The most obvious function of evaluation is to express the speaker's opinion, that is, to convey what the speaker thinks or how s/he feels about something [...]. This in turn can reflect the ideology and the system of values of a social group.” (159)

Thus, evaluation can be seen as a complex process of assessment through the prisms of individual and social perceptions.

Evaluation may be expressed verbally and non-verbally. The later involves body language, gestures, facial expressions, the pitch of voice, and the like. One of the examples of nonverbal evaluation can be a 'thumbs-up' gesture to indicate that you approve or accept something, whereas 'thumbsdown' demonstrates your rejection or disapproval.

Verbal evaluation "permeates all the levels of linguistic description" (Alba-Juez and Thompson 10), however, it is not a compulsory feature of a word and there are many lexemes that are devoid of evaluative meaning or express it only in a certain context (Examples 1 and 2). Hence, evaluation can be explicit or implicit. Explicit evaluation straightforwardly states the person's judgement or attitude towards somebody or something (e.g. gorgeous, horrible). On the other hand, implicit evaluation may be realised in two ways: a) when a neutral language item occurs in such contextual setting that it acquires an evaluative meaning (Example 2), and b) an apparently positive lexeme may be used to denote the opposite concept and vice-versa (Examples 3 and 4). 
(1) I saw a monkey in the zoo.

(2) “You are an impertinent little monkey!” (Bronte 96)

(3) $[\ldots]$ my dear girl confidently answered 'No' too and shook the lovely head which, with its blooming flowers against the golden hair, was like the very spring. 'Much YOU know of east winds, my ugly darling,' [...]. (Dickens 482)

(4) Of these, foremost in the front rank stands Volumnia Dedlock, a young lady (of sixty) [...]. (Dickens 446)

In sentence (1) the word monkey has a non-evaluative use, while in sentence (2) it is undoubtedly evaluative and characterises a person as naughty or mischievous. In Example (3) the adjective ugly does not signify an unpleasant appearance of a girl, on the contrary, its use accentuates the beauty of the girl and affection for her the other character has. The use of the adjective young in Example (4) to characterize an elderly lady gives this depiction an ironic flavor.

Generally speaking, evaluation is explicit when a language unit is used in context in its primary denotative meaning and implicit evaluation happens when a language entity acquires some additional connotative meaning in the context. Thompson and Hunston ascertained four parameters of evaluation: good/ bad, certainty, expectedness and importance (22-25). The good/ bad parameter is the fundamental one as it directly entails positive or negative attitude, assessment, opinion, judgement, and so on. The other parameters, although important for the concept of evaluation on the whole, are not so relevant in personality characterization. Therefore, the good/ bad parameter was chosen in the present research to study the use of evaluative adjectives in women portrayals.

\section{EVALUATIVE ADJECTIVES: NATURE AND TYPES}

Although various parts of speech (e.g. nouns, modal verbs, adverbs, etc.) can express evaluation, adjectives are traditionally considered as the most obvious means of communicating this concept, since "most typically, adjectives describe qualities of people, things, and states of affairs" (Biber $e t$ al. 64). Linguists suggested different classifications of adjectives according to their morphological, syntactic and semantic characteristics (cf. Biber et al. 2007, Marzá 2011, Quirk et al. 1985 and others). Since semantic classification of adjectives is of particular interest for this study, a brief overview of some of them is given in this section.

Quirk et al. apply three semantic scales to adjectives: 'stative'/ 'dynamic', 'gradable'/ 'nongradable', and 'inherent'/ 'noninherent'. According to them, adjectives are characteristically stative (e.g, tall); 
however, those that express subjective measurement (e.g., careful) are regarded as dynamic. All dynamic and most stative adjectives are gradable, although some stative (e.g. atomic) are not. Most adjectives are inherent and characterize the referent of the noun directly (e.g., soft touch), whereas modification of a noun by a noninherent adjective is seen as an extension of the meaning of the noun (e.g., firm friend) (434-35). The authors do not single out a special semantic class of evaluative adjectives yet mention "epithets (noun or adjective phrases)" expressing favourable/ unfavourable evaluation among the various forms of vocatives (e.g. (my) darling, (my) dear, bastard, coward) (Quirk et al. 774). In fact, dynamic adjectives, listed by the authors (Quirk et al. 434) can be seen as the ones that give subjective positive or negative characterization of the referent, e.g.: abusive, cheerful, gentle, impudent, etc.

In their turn, Biber et al. distinguish two semantic groups of adjectives: 'descriptors' and 'classifiers'. The first are typically gradable and denote a wide range of characteristics (e.g. new, wide), at the same time, "the primary function of classifiers is to delimit or restrict a noun's referent, by placing it in a category in relation to other referents" (508). Among the selected examples of descriptors, the authors discriminate 'evaluative'/ 'emotive' adjectives that designate judgements, affect, emphasis: e.g., bad, beautiful, best and others. Besides, grammarians draw attention to some semantic features of adjective: a) adjectives may have a range of meanings (e.g., old can describe the age as in old radio and denote affectionate attitude poor old Rusty); b) some adjectives can serve as either classifiers or descriptors (compare: criminal law vs criminal activity); c) grammatical role of adjectives can be associated with a particular meaning (e.g., poor used predicatively refers to financial circumstances, while in the attributive use it has a wider range of meanings, including the emotive meaning (poor little bastards); d) the characteristic uses of an adjective often differ across registers (e.g. in academic prose poor is generally descriptive, whereas in fiction it is commonly emotive) (Biber et al. 509); e) semantically, the predicative adjectives in fiction tend to be descriptive of a state of mind or emotion (e.g. afraid, aware, glad, happy, ready, sure, tired) (Biber et al. 518).

Although, Biber et al. differentiate evaluative adjectives as a specific domain of gradable adjectives unlike Quirk et al., the semantic changes in the meaning of adjectives listed above give grounds to suppose that evaluation is more than just the meaning of adjectives, since it may depend on their function as well as on the context itself.

According to Swales and Burke, gradable adjectives occupy various points along a continuum, with strongly negative adjectives at one pole, strongly positive at the other, and the more neutral adjectives in the 
intermediate position. The authors placed the adjectives into one of the following seven categories: 'acuity', 'aesthetic appeal', 'assessment', 'deviance', 'relevance', 'size', and strength, but admitted that both creating the categories and placing adjectives within them are somewhat subjective (4-5). Their views on the three types of evaluation, i.e. positive, neutral, negative are supported in this study, and stative adjectives like tall are also considered evaluative, but devoid of positive or negative emotional colouring. Concerning the differentiated seven categories, they do not have clear-cut criteria which adjective should go into which category, and sometimes it is impossible to identify the correct category for a lexeme even in context. For example, the adjective feeble may denote: a) "frail"; "weak"; b) "inadequate"; "unconvincing"; c) "easily influenced or indecisive", as stated in the Collins English Dictionary, and even the following context does not help much to place it into one category as several options are possible, e.g.: "[...] how noble in him to support the feeble sisters on such majestic crutches!" (Dickens 844).

Finally, Kochetova and Volodchenkova divided adjectives into 'evaluative' and 'descriptive', “the former conveying the speaker's attitude to the referent (the perceived qualities), the latter stating the "objectively present" (factual or absolute) qualities" (293). For example, ambitious is an evaluative adjective since it not only expresses the idea that the referent is determined to succeed but also that this is a good thing, while the adjective furnished is descriptive, for no obvious connotation is observed. Evaluative adjectives are subdivided into adjectives of general evaluation (generallypositive/ generally-negative), qualifying the referent as generally good or bad and adjectives of specific evaluation (positive/ negative) characterizes a certain facet of the referent (e.g. beautiful, intelligent, etc.) (Kochetova and Volodchenkova 293). This classification of adjectives was adapted for the present study and, after analyzing the use of evaluative adjectives in the women portrayals, adjectives giving generally positive and generally negative characterisations were also singled out.

Thus, the term 'evaluative' is understood in the present study in its broad sense as defined by Hunston and Thompson (5) and applying it to adjectives it can be stated that an adjective is evaluative when it is used to express the speaker or writer's attitude or stance towards the referent, her/ his viewpoints or feelings about the characterised entities. In such a way, all adjectives may convey an evaluative meaning that can be either explicit or implicit as to the mode of it expression and positive, negative or neutral depending on their emotional colouring. 


\section{DATA AND METHODOLOGY}

The research is based on the corpus of evaluative adjectives retrieved and classified from the four novels written in the Victorian era of the English literature (1830-1901): E. Bronte's Wuthering Heights, W. M. Thackeray's Vanity Fair, E. Gaskell's Cranford, and C. Dickens's Bleak House. This era is considered to be the golden age in the history of Great Britain, distinguished by the growing capital and power and the rapid pace of industrial and social changes. It is also a noticeable epoch of flourishing of prose fiction that "had reached full parity with the other types of literature in critical esteem, and had surpassed them in popular appeal” (Bloom 49). Female characters depicted in the novels of this period received the most vivid portrayal and over the centuries they served as aesthetic models for many writers and literary critics.

The novels analysed were written approximately in the same period of time, in the middle of the $19^{\text {th }}$ century, which means their authors were experiencing the same influence of the then society with its economic and social problems, the system of values, religion, prejudice, and other issues.

The goal of the research was to study whether women were positively or negatively characterised in the novels of that historical period, therefore adjectives expressing positive or negative characterisation of the female characters in the novels, both explicit and implicit, were manually selected. Two online dictionaries i.e. Collins Dictionary and Oxford Learner's dictionaries were used to clarify the meaning of the adjectives. Thus, women characters received explicit evaluation when positive or negative characterisation was inherent in the denotative meaning of an adjective, e.g. comely - "(especially of a woman) pleasant to look at" (Oxford). Dictionary comments such as approving/ disapproving in the Oxford Learner's dictionaries or approval/ disapproval in Collins Dictionary helped to recognize implicit evaluation of a woman as well as the context in which the adjective was used (Examples 2-4).

The whole corpus of evaluative adjectives was divided into two groups: adjectives of positive evaluation and adjectives of negative evaluation, and neutrally coloured adjectives were not regarded in this study. Both groups were further subdivided into several subgroups according to what adjectives described: general characterisation, physical appearance, intellectual abilities, clothing, personal traits, manner or behavior, and emotional state/ feelings. The following sections provide a more detailed account of the results of the research. 


\section{POSITIVE EVALUATION OF WOMEN CHARACTERS}

Altogether 3815 adjectives conveying positive evaluation of women characters were found in the novels. Having analysed and compared their use, the groups of the most frequent ones were singled out for every novel separately, with frequency of occurrence $2 \%$ and higher of the general number of adjectives denoting positive evaluation in each novel. It should be noted that these groups constitute approximately half of all adjectives of positive evaluation in every novel and the other half comprises the adjectives that occurred with a frequency of $1 \%$ or lower. Table 1 shows the quantitative results of the analysis, presenting the most frequent adjectives, which provide a positive evaluation of women characters.

Table 1 Frequency of adjectives giving a positive evaluation of women characters in the novels ${ }^{1}$

\begin{tabular}{|l|c|l|c|l|c|l|c|}
\hline \multicolumn{2}{|c|}{$\begin{array}{c}\text { Wuthering } \\
\text { Heights }\end{array}$} & \multicolumn{2}{c|}{ Cranford } & \multicolumn{2}{c|}{ Vanity Fair } & \multicolumn{2}{c|}{ Bleak House } \\
\hline $\begin{array}{l}\text { Evaluative } \\
\text { adjectives }\end{array}$ & $\%$ & $\begin{array}{l}\text { Evaluative } \\
\text { adjectives }\end{array}$ & $\%$ & $\begin{array}{c}\text { Evaluative } \\
\text { adjectives }\end{array}$ & $\%$ & $\begin{array}{c}\text { Evaluative } \\
\text { adjectives }\end{array}$ & $\%$ \\
\hline little & 13 & dear & 15 & little & 14 & little & 14 \\
\hline good & 6 & little & 6 & dear & 11 & dear & 13 \\
\hline sweet & 6 & pretty & 6 & good & 3 & good & 6 \\
\hline glad & 5 & honourable & 5 & kind & 3 & old & 6 \\
\hline dear & 4 & glad & 4 & gentle & 3 & pretty & 4 \\
\hline amiable & 2 & good & 4 & great & 3 & beautiful & 2 \\
\hline beautiful & 2 & kind & 4 & tender & 3 & glad & 2 \\
\hline gentle & 2 & gentle & 3 & good-natured & 2 & great & 2 \\
\hline grand & 2 & great & 2 & happy & 2 & handsome & 2 \\
\hline great & 2 & soft & 2 & innocent & 2 & happy & 2 \\
\hline pretty & 2 & tender & 2 & pretty & 2 & & \\
\hline not afraid & 2 & & & sweet & 2 & & \\
\hline
\end{tabular}

As can be seen from Table 1, there are five adjectives of positive evaluation that occurred most often in women characterisation by the male and female authors i.e. little, dear, good, pretty and great. The adjective little was regarded only when it was used to show affection (Example 5), therefore the instances where it was used to denote size or age (Example 6) were not counted since they do not have an emotive component.

(5) Poor little Emmy--dear little Emmy. (Thackeray 135)

\footnotetext{
${ }^{1}$ The grey-coloured parts in the tables show the research results of the use of evaluative adjectives found in the novels written by male authors.
} 
(6) Nay, the acute observer might have recognized the little red nose [...]. (Thackeray 7)

Likewise, the adjective great was counted only in those cases when it was used in the meaning "extremely good in ability or quality and therefore admired by many people" or "very good or pleasant" (Oxford) (Example 7). The adjective dear was differentiated in the study from the nominal phrase (my) dear (Examples 8 and 9) or exclamation (Oh, dear; Dear me, etc.), and the adjective old was calculated when it was used with the noun girl, as a friendly form of address of a husband to a wife in the novel Bleak House (Examples 10).

(7) I speak of really a great lady, not merely great to him [...]. (Dickens 629)

(8) "It is quite a different sort of thing, my dear madam," he began. (Gaskell 10)

(9) "Have you drawers enough, dear?" asked she. (Gaskell 26)

(10) Whatever the old girl says, do--do it!" (Dickens 441)

The results show there are no marked gender differences between the authors in their choice of the most frequent lexemes to give a positive characterisation of women heroines. This selection of adjectives creates an image of a woman as a weak, good looking, and delightful creature. Such image corresponds to the conventional view on the status and social role of women in the Victorian society.

A woman being more delicate, fragile, reserved, yet virtuous, loving, and pretty was properly confined to the household sphere where her gentleness and nurturing were best employed. (Loeb 19)

Table 2 provides a more detailed account of the percentage of adjectives of positive evaluation used to describe various facets of female characters in the novels as well as the prevailing lexemes used in the corresponding subgroups.

Table 2 Subgroups of adjectives of positive evaluation

\begin{tabular}{|c|c|c|c|c|c|c|c|}
\hline & $\begin{array}{c}\text { general } \\
\text { characterisation }\end{array}$ & $\begin{array}{c}\text { physical } \\
\text { appearance }\end{array}$ & $\begin{array}{c}\text { intellectual } \\
\text { abilities }\end{array}$ & clothing & $\begin{array}{c}\text { personal } \\
\text { traits }\end{array}$ & $\begin{array}{c}\text { manner/ } \\
\text { behavior }\end{array}$ & $\begin{array}{c}\text { emotional } \\
\text { state/ } \\
\text { feelings }\end{array}$ \\
\hline & $\%$ & $\%$ & $\%$ & $\%$ & $\%$ & $\%$ & $\%$ \\
\hline \multirow{2}{*}{$\begin{array}{c}\text { Wuthering } \\
\text { Heights }\end{array}$} & 37 & 20 & 5 & 1 & 14 & 12 & 11 \\
\cline { 2 - 8 } & little & $\begin{array}{c}\text { pretty/ } \\
\text { beautiful }\end{array}$ & keen & neat & good & amiable & glad \\
\hline Cranford & 40 & 16 & 2 & 2 & 17 & 14 & 9 \\
\cline { 2 - 8 } & dear & pretty & clever & neat & kind & tender & glad \\
\hline \multirow{2}{*}{\begin{tabular}{l} 
Vanity \\
\cline { 2 - 8 }
\end{tabular}} & 46 & 9 & 2 & 1 & 21 & 16 & 5 \\
\hline
\end{tabular}




\begin{tabular}{|c|c|c|c|c|c|c|c|}
\hline \multirow{2}{*}{$\begin{array}{c}\text { Bleak } \\
\text { House }\end{array}$} & 43 & 18 & 3 & 1 & 21 & 7 & 7 \\
\cline { 2 - 8 } & little & pretty & sagacious & neat & good & sweet & happy \\
\hline
\end{tabular}

Judging by these results all novelists preferred to give a general positive characterisation of women and fewer adjectives were used to describe women's intellectual abilities and clothing. For male novelists, the personal traits of women characters were more important than their appearance; however, for the female novelists, pleasant appearance of heroines was more significant.

\section{NEGATIVE EVALUATION OF WOMEN CHARACTERS}

The conducted research allowed singling out 2374 adjectives of negative evaluation of women characters in the novels. Lexemes with a frequency of occurrence of $2 \%$ and higher of the general number of adjectives denoting negative evaluation in each novel are presented in Table 3.

Table 3 Frequency of adjectives giving a negative evaluation of women characters in the novels

\begin{tabular}{|l|c|l|c|l|c|l|c|}
\hline \multicolumn{2}{|c|}{$\begin{array}{c}\text { Wuthering } \\
\text { Heights }\end{array}$} & \multicolumn{2}{c|}{ Cranford } & \multicolumn{2}{c|}{ Vanity Fair } & \multicolumn{2}{c|}{ Bleak House } \\
\hline $\begin{array}{c}\text { Evaluative } \\
\text { adjectives }\end{array}$ & $\%$ & $\begin{array}{l}\text { Evaluative } \\
\text { adjectives }\end{array}$ & $\%$ & $\begin{array}{c}\text { Evaluative } \\
\text { adjectives }\end{array}$ & $\%$ & $\begin{array}{c}\text { Evaluative } \\
\text { adjectives }\end{array}$ & $\%$ \\
\hline poor & 6 & poor & 12 & poor & 24 & poor & 10 \\
\hline naughty & 4 & afraid & 6 & angry & 2 & sorry & 4 \\
\hline afraid & 3 & anxious & 6 & miserable & 2 & afraid & 3 \\
\hline angry & 3 & angry & 2 & pale & 2 & proud & 3 \\
\hline sorry & 3 & annoyed & 2 & sad & 2 & anxious & 2 \\
\hline wicked & 3 & bewildered & 2 & silly & 2 & brimstone & 2 \\
\hline wild & 3 & fluttered & 2 & simple & 2 & confused & 2 \\
\hline anxious & 2 & indignant & 2 & timid & 2 & frightened & 2 \\
\hline pale & 2 & nervous & 2 & unhappy & 2 & mad & 2 \\
\hline sad & 2 & sad & 2 & & & old & 2 \\
\hline silly & 2 & weak & 2 & & & shy & 2 \\
\hline & & & & & & worn & 2 \\
\hline
\end{tabular}

Unlike the positive evaluation of women authors use the wider scale of adjectives expressing their negative assessment and only one lexeme poor, denoting those "deserving of pity; unlucky" (Collins), was observed in all four novels (Examples 11 and 12).

(11) Poor Martha! I think she'll be sorry to leave me. (Gaskell 126)

(12) I nursed her, poor thing! (Bronte 30) 
The extensive use of this lexeme by the authors may also indicate the women's weakness and helplessness. Table 4 presents how frequently adjectives of negative evaluation were used to characterise different aspects of heroines and the most frequent ones in each subgroup.

Table 4 Subgroups of adjectives of negative evaluation

\begin{tabular}{|c|c|c|c|c|c|c|c|}
\hline & $\begin{array}{c}\text { general } \\
\text { characterisation }\end{array}$ & $\begin{array}{c}\text { physical } \\
\text { appearance }\end{array}$ & $\begin{array}{l}\text { intellectual } \\
\text { abilities }\end{array}$ & clothing & $\begin{array}{l}\text { personal } \\
\text { traits }\end{array}$ & $\begin{array}{l}\text { manner/ } \\
\text { behavior }\end{array}$ & $\begin{array}{l}\text { emotional } \\
\text { state/ } \\
\text { feelings }\end{array}$ \\
\hline & $\%$ & $\%$ & $\%$ & $\%$ & $\%$ & $\%$ & $\%$ \\
\hline \multirow{2}{*}{$\begin{array}{c}\text { Wuthering } \\
\text { Heights }\end{array}$} & 17 & 10 & 5 & 0 & 13 & 20 & 35 \\
\hline & poor & pale & silly & - & cruel & naughty & afraid \\
\hline \multirow{2}{*}{ Cranford } & 23 & 9 & 1 & 1 & 9 & 16 & 40 \\
\hline & poor & worn & ignorant & shabby & $\begin{array}{l}\text { impatient } \\
\text { / timid }\end{array}$ & uneasy & afraid \\
\hline \multirow{2}{*}{ Vanity Fair } & 39 & 9 & 6 & 1 & 12 & 14 & 19 \\
\hline & poor & pale & simple & shabby & timid & killing & sad \\
\hline \multirow{2}{*}{$\begin{array}{l}\text { Bleak } \\
\text { House }\end{array}$} & 21 & 12 & 7 & 4 & 17 & 20 & 20 \\
\hline & poor & worn & mad & shabby & proud & confused & sorry \\
\hline
\end{tabular}

As can be seen, male novelists preferred general characterisation of the women, while female novelists favoured depicting the heroines' emotional state or feelings, having mostly used the adjective afraid. Similar to positive evaluation, not much attention was given to women's clothing, although writers used somewhat more adjectives to provide a negative assessment of women's intellectual abilities. Male and female authors used the same negative lexemes to give women's general characterisation, to describe physical appearance and clothes but used a wide range of adjectives of negative evaluation to portray other aspects of female characters.

\section{COMPARISON OF THE USE OF THE EVALUATIVE ADJECTIVES}

The present research compared the use of evaluative adjectives in the description of women characters in the four novels of the Victorian era. The whole corpus of the evaluative adjectives found in the novels constitutes 6189 lexemes and the total amount of adjectives giving positive characterisation - 3815 lexemes and negative - 2374 (Table 5).

Table 5 Total amount of adjectives of positive and negative evaluation of women characters in the novels

\begin{tabular}{|l|c|c|c|c|}
\hline & \multicolumn{2}{|c|}{$\begin{array}{c}\text { Adjectives of positive } \\
\text { evaluation }\end{array}$} & \multicolumn{2}{c|}{$\begin{array}{c}\text { Adjectives of negative } \\
\text { evaluation }\end{array}$} \\
\hline Wuthering Heights & 219 & $37 \%$ & 366 & $63 \%$ \\
\hline Cranford & 285 & $50 \%$ & 289 & $50 \%$ \\
\hline
\end{tabular}




\begin{tabular}{|l|l|l|l|l|}
\hline Vanity Fair & 1938 & $68 \%$ & 921 & $32 \%$ \\
\hline Bleak House & 1373 & $63 \%$ & 798 & $37 \%$ \\
\hline
\end{tabular}

Despite the fact that adjectives of positive evaluation prevail in the corpus retrieved from the novels this cannot be taken as a straightforward fact because of the different length of the novels written by male and female writers, i.e. the latter were shorter.

The closer examination of the peculiarities of the use of evaluative adjectives in the novels shows that female and male novelists used different quantity of adjectives expressing positive and negative evaluation, at least within the scope of this study. Thackeray and Dickens used considerably more adjectives conveying positive evaluation to portray women characters. At the same time, Brontë chose more adjectives expressing the negative evaluation of heroines and Gaskell made use of an approximately equal number of adjectives of positive and negative evaluation.

Such results show the writers' general attitude to their female characters, their intentions to present women in the way they wanted them to be seen and understood by the reader.

\section{CONCLUSIONS}

To sum up, this study examines the use of evaluative adjectives in the portrayal of women characters in the four novels written almost at the same period of the Victorian era. Evaluative adjectives are regarded in this research as the ones that are used to express the writer's attitude or stance, viewpoints or feelings about the female characters. Adjectives may convey evaluative meaning explicitly or implicitly and express positive, negative or neutral evaluation depending on their emotional colouring. This study deals only with the adjectives expressing positive or negative evaluation.

The corpus findings show that there are gender differences between the authors in the quantity of adjectives they used to give the positive and negative evaluation of heroines. Contrary to male writers who favoured adjectives of positive characterisation, female writers used either almost the same amount of positive or negative adjectives (Gaskell) or gave preference to the negative ones (Brontë) in the description of women characters.

However, the examination of the corpus allowed revealing that there are no significant differences between the writers in the choice of the most frequently used adjectives of positive evaluation and far more variations of adjectives giving a negative evaluation of women characters. The authors' choice of the most frequent lexemes creates the image of a woman as a weak, helpless creature, which corresponds to the attitude to women in the Victorian society. 
Finally, it is also worth noting that male writers preferred to use adjectives that give general positive or negative characterisation of women characters, whereas female writers favoured negative adjectives in portraying heroines' emotional states or feelings. The smallest number of adjectives was used to characterise the women's intellectual abilities and clothing in a positive or negative way by all authors.

It may be concluded that the research only delineated the possible ways to study evaluative adjectives and further investigations will allow getting a better understanding of these lexemes.

\section{Works Cited}

Alba-Juez, Laura and Geoff Thompson. "The Many Faces and Phases of Evaluation.” Evaluation in Context. Eds Geoff Thompson, Laura Alba-Juez. Amsterdam/ Philadelphia: John Benjamins Publishing Company, 2014. 3-26. Print.

Biber, Douglas, Stig Johansson, Geoffrey Leech, Susan Conrad, and Edward Finegan. The Longman Grammar of Spoken and Written English. 6th impression. London: Pearson Education Limited, 2007. Print.

Bronte, Emily. Wuthering Heights. New York: Bantam Classics, 1981. Print.

“comely”. Oxford Learner's Dictionaries.com. Oxford, 2017. Web. 10 August 2017.

Dickens, Charles. Bleak House. London: Penguin Books, 1985. Print.

Escandell-Vidal, Victoria Marrero Aguiar and Pilar Pérez Ocón. "Prosody, Information Structure and Evaluation." Evaluation in Context. Eds Geoff Thompson, Laura Alba-Juez. Amsterdam/ Philadelphia: John Benjamins Publishing Company, 2014. 153-178. Print.

"feeble". Collins Dictionary.com. Collins, 2017. Web. 10 August 2017.

Gaskell, Elizabeth. Cranford, Oxford: Oxford University Press, 2011. Print.

"great". Oxford Learner's Dictionaries.com. Oxford, 2017. Web. 10 August 2017.

Hunston, Susan and Geoff Thompson, eds. Evaluation in Text. Authorial Stance and the Construction of Discourse. Oxford: Oxford University Press, 2000. Print.

Kochetova, Larisa Anatolyevna and Olga Ivanovna Volodchenkova. "Evaluative Language in English Job Advertisements in Diachronic Perspective". Review of European Studies; 7.11 (2015): 292-302. Print.

Loeb, Lori Anne. Advertising and Victorian Women. Oxford: Oxford University Press, 1994. Print.

Martin, J. R. and P. R. R. White. The Language of Evaluation. Appraisal in English. New York: Palgrave Macmillan. 2005. Print.

Marzá, Nuria Edo. “A Comprehensive Corpus-based Study of the Use of Evaluative Adjectives in Promotional Hotel Websites". Odisea 12 (2011): 97-123. Print.

Ochs, Elinor and Bambi Schieffelin. "Language Has a Heart.” Text 9.1 (1989): 7-25. Print.

“poor”. Collins Dictionary.com. Collins, 2017. Web. 10 August 2017. 
Quirk, Randolf, Sidney Greenbaum, Geoffrey Leech, and Jan Svartvik. A Comprehensive Grammar of the English Language. London: Longman Group Limited, 1985. Print.

Stevenson, Lionel. "The Modern Values of Victorian Fiction.” The Victorian Novel (Bloom's Period Studies). Ed. Harold Bloom. New York: Chelsea House, 2004. 43-53. Print.

Thackeray, William Makepeace. Vanity Fair. London: Penguin Classics, 2002. Print.

Thompson, Geoff and Susan Hunston. "Evaluation: An introduction.” Evaluation in Text. Eds. Susan Hunston and Geoff Thompson. Oxford: Oxford University Press, 2000. 1-27. Print. 